\title{
Sustainable Finance at the time of Institutions : Performativity through the lens of Responsible Management in Morocco
}

http://doi.org/10.21272/fmir.4(2).52-64.2020.

Adil El Amri, ORCID: https://orcid.org/0000-0003-1849-8727

Professor, Member of MAD Laboratory and LERSEM Laboratory, Higher School of Technology of Sidi Bennour, Coordinator: Professional Bachelor's degree: Management \& Administration of Organizations, F.P.S.B., University of Chouaib Doukkali, El Jadida, Morocco

\section{Rachid Boutti}

Professor, President of the Chair UNESCO Sustainable Development, Founder of LaRGe Laboratory, Director of the CREMA Indexed International Journal and Expert at the CNRS, Agadir, Morocco

\section{Florence Rodhain}

Professor, Director of the MRM-SI Research Team, University Polytechnic School, University of Montpellier, Montpellier, France

\begin{abstract}
The aim of this study is to evaluate the level of Sustainable Finance disclosure in Institutions and to analyze the relationship between Performativity of Responsible Management and Sustainable Finance. A Performativity of Sustainable Finance through the lens of Responsible Management is constructed. To verify the link between the impact of responsible strategies and structures on the implementation and deployment of Sustainable Finance for reducing $\mathrm{CO} 2$ emissions at the time of Institutions, the structural relationships in our model are run. Although several studies have investigated the Sustainable finance, the issue of adoption and performance through the prism Responsible Management remains open. This allowed us to conduct empirical research through a questionnaire involving key axes of our study. We targeted primarily a sample of 40 companies ELEC EXPO International Forum in Casablanca, Morocco, held from 04 ${ }^{\text {th }}$ to $07^{\text {th }}$ October 2018. We review the carbon finance strategies, analyze its relationship with the structure of the compliance New Economic Regulations and ISO 26000 . Subsequently, we assess the validity of its performance and its adoption prism Responsible Management through a reflexive model. To achieve this, we tested the structural relationships in our model, as the reflective nature of our built and predictive vocation of our model led us to retain the method Partial Least Squares as part of the validation of our research model. Our choice of using the Partial Least Squares approach is justified by the fact that it can treat analyzes on samples of reduced size ( $<100$ observations). Ultimately, some of the literature says that strategies of Sustainable Finance include three dimensions. Indeed, the results indicate two important pillars for the performance of the adoption of the Sustainable Finance for the Moroccan plan; Clean Development Mechanism strategy and structure of the compliance New Economic Regulations and ISO 26000 . We then discuss the theoretical and practical implications of this managerial discovery.
\end{abstract}

Keywords: Sustainable Finance, Joint Implementation (JI), Clean Development mechanism (CDM), Emissions Permits Negotiable (PEN), Responsible Management

JEL Classification: G30, O16, Q01, Q51, Q54.

This work is licensed under a Creative Commons Attribution 4.0 International License

Cite as: El Amri, A., Boutti, R., Rodhain, F. (2020). Sustainable Finance at the time of Institutions: Performativity through the lens of Responsible Management in Morocco. Financial Markets, Institutions and Risks, 4 (2), 52-64. http://doi.org/10.21272/fmir.4(2).52-64.2020.

(C) The Authors, 2020. This article is published with open access at Sumy State University.

\section{Introduction}

The field of Sustainable Finance through the lens of Responsible Management seems more occupied by the managers than by the economists. Thus it is that among the many works devoted to this theme, few have 
studied specifically the performance of the adoption of Sustainable Finance, while the latter are the preferred vehicle of implementation and the deployment of Sustainable Finance.

In the context of this research, we are going to two basic objectives. The first was to evaluate and assess the strategic involvement of environmental firms registered at the Forum International ELEC EXPO in Casablanca, Morocco, working in the Renewable Energy (Re), Energy Efficiency (EE) and Green IT ; strategic areas of Sustainable Finance, the Responsible Management and Sustainable Development (Boutti, El Amri, Rodhain, 2019).

We are going to study through this research question the Performance of the Adoption of Sustainable Finance through the lens of Responsible Management in the light of some specific characteristics of companies surveyed (size measured by number of staff, the territoriality or nationality, contribution of the use of Renewable Energy, greenhouse Gas Emissions of the activity and level of education in engineering, Top Management).

In this regard, the second objective will be to analyze, test and assess the validity of the Performance of the Adoption of Sustainable Finance through the lens of Responsible Management through a model of reflexive thinking. However, we reviewed the strategies of Sustainable Finance and we analyzed its relationship with the structure of the compliance with NRE (New Economic Regulations) and ISO 26000 . To achieve this, we will develop a questionnaire which included three distinct parts : a first part dedicated to general information and in the Responsible Management and Sustainable Development (SD). A second part is dedicated to the three (3) strategies for Sustainable Finance, namely : CDM, JI and PEN, this part is in choosing one of these strategies in order to put in force the strategy to focus on the Performance of the Adoption of Sustainable Finance through the lens of Responsible Management in the moroccan context. As to the last part of the questionnaire, it was related to the structure of the compliance NRE and practices ISO 26000.

\section{Literature Review}

The creation of value in the short term for the investors is the sole criterion of performance allowed in the model of financial capitalism, which makes it an effective way to finance the real economy. Of course, this system has demonstrated its capacity to boost innovation, and has been able to prove a real mine of wealth for those who control it, however, it has some major drawbacks, which earned him the title of model cynical (Cosgrove-Sacks and Dembinski, 2009).

Its economic logic does not consider automatically the interest of the man and of his environment as a priority. In fact, capitalism offers a distribution of wealth that has been qualified as evil, and totally opposed to the notions of solidarity and humanity (Kostel, Leus, Cebotarenco and Mokrushina, 2017).

In this financial universe, where the speculation and the requirements of profitability prevail, the idea of a coexistence of finance and of social responsibility, seems absurd. However, the surface between the two is not necessarily waterproof. To this end, we are witnessing the emergence of a new mode of management, concerned with the environmental problems, and who tries to balance responsibility and performance. It is the Investment in Socially Responsible (SRI).

Indeed, the desire to establish an economy that respects people and the environment is palpable on the international scene, and this through several initiatives, including one to cite, the ratification of the Kyoto Protocol, which commits industrialized countries to reducing emissions of greenhouse gases, and the establishment in 2006 of the universal principles of sustainability by the United Nations under the name United Nations Principles for Responsible Investment' (Bhandari, 2019).

The structures of conformity - New Economic Regulations (NRE) and ISO 26000 - face-of-many built and it can hardly be ruled out that the Performance of the adoption of Sustainable Finance may depend significantly from the managerial practices, managers work in organizations (Jaffe, Newell \& Stavins, 2004 ; IEA Ministerial Statement on Energy and Climate Change, 2015 ; ISO, 2010 ; World Business Council for Sustainable Development, 1998 ; World Resources Institute, 1998).

At the same time, the strategy the Clean Development mechanism (CDM) is more than ever regarded as the key element to the success of Sustainable Finance as a central concern in the Kyoto Protocol (KP) is to now find the best way to create a Clean Development in the Countries of the South. Therefore, it is clear that the Strategy of the Emissions Permits Negotiable (PEN) - defined as an opportunity to sell and purchase of quotas and credits $\mathrm{CO} 2$ vis-à-vis an industrial player registered in a stock exchange for carbon ; the cases for 
illustration of the European Union Emissions Trading System (EU ETS) seems to be particularly important in the implementation and deployment of Finance for Sustainable in a community setting.

With regard to the Joint Implementation (JI), based on the achievement of emission credits for carbon, converted into quotas, through an investment in a certified project 'performance in CO2-emission (Boutti, El Amri and Rodhain, 2019).

\section{Conceptual model and operationalization of concepts of the research model}

Our goal in this research, in this case, is to present faithfully the steps of the process of measurement of the dimensions of the concepts of our research, their construct validity, convergent and discriminant, their reliability as a measure and as a concept as well as their consistency.

We are trying to verify the four (4) following assumptions are made in the context of our ear-model search :

Research Hypothesis 1 (H1) : The strategy of the Clean Development mechanism (CDM) positively influences the performance of the adoption of Sustainable Finance through the lens of Responsible Management in organizations.

$>\quad$ Research Hypothesis 2 (H2) : The strategy of the Joint Implementation (JI), has a positive impact on the performance of the adoption of Sustainable Finance through the lens of Responsible Management in organizations

$>\quad$ Research Hypothesis 3 (H3) : The strategy of the Emissions Permits Negotiable (PEN) promotes positively the deployment and implementation of the performance of the adoption of Sustainable Finance through the lens of Responsible Management in organizations.

Research Hypothesis 4 (H4) : The implementation and deployment of the structures of conformity NRE and ISO 26000 improve positively the performance of the adoption of Sustainable Finance through the lens of Responsible Management in organizations.

The interest for our research is to understand the strategies and structures Performance-enhancing Adoption of Sustainable Finance through the lens of Responsible Management in the moroccan context. Thus, our central question of our research has been formulated in the following way :

"What are the strategies and structures Performance-enhancing Adoption of Sustainable Finance through the lens of Responsible Management plan moroccan ?»

To test our meta-model can be conceptually designed by an approach to abductive, we are making a transition from the theoretical world to the world empirical. This transition is not without its pitfalls, methodological, requires a certain vigilance as to the choice of good proxies to identify the major facets or dimensions of the concepts in our model, as well as to test their interactions. Driven by this purpose, we will split up this axis in two essential points. The first is to highlight the methodology to test the validity and reliability of the variables of operationalization. In a second point, we are strengthening the choice of the methodology to test the validity and reliability of variables for the operationalization of our meta-model.

\subsection{Methodology to test the validity and reliability of variables operationalization}

It is clear that when the research is to confront assumptions of factual data bearing on the qualitative concepts, the use of the operationalization of the latter by a measuring instrument remains inevitable. This instrument takes the form of a questionnaire with scales in the form of questions with items.

We synthesize finally, all steps of the verification procedure of the validity and the reliability of our measurement models in the following table. 
Table 1. Results of the Exploratory Factor Analysis (AFE) and Confirmatory Factorial Analysis (AFC)

\begin{tabular}{|c|c|c|c|c|c|c|c|c|c|c|c|}
\hline \multirow[b]{2}{*}{ Concept/built } & \multicolumn{2}{|c|}{ Conceptual Phase } & \multicolumn{3}{|c|}{ Results of the Exploratory Factor Analysis (AFE) } & \multicolumn{5}{|c|}{ Results of Confirmatory Factorial Analysis (AFC) } & \multirow{2}{*}{$\begin{array}{c}\begin{array}{l}\text { Measurement } \\
\text { model final }\end{array} \\
\begin{array}{c}\text { Number of } \\
\text { items retained } \\
\text { in the }\end{array} \\
\text { measurement } \\
\text { model } \\
\end{array}$} \\
\hline & Dimensions & $\begin{array}{c}\text { Number } \\
\text { of item }\end{array}$ & $\begin{array}{c}\text { Number of items } \\
\text { correlated } \\
\text { positively and }\end{array}$ & $\begin{array}{c}\text { Total } \\
\text { Variance } \\
\text { explained }\end{array}$ & $\begin{array}{c}\text { Cronbach's } \\
\text { Alpha }\end{array}$ & $\begin{array}{l}\text { Average } \\
\text { variances } \\
\text { extracted }\end{array}$ & $\begin{array}{r}\text { Impa } \\
\text { va } \\
\text { va }\end{array}$ & $\begin{array}{l}\text { of the latent } \\
\text { ble on the } \\
\text { bles overt }\end{array}$ & $\begin{array}{l}\text { Indicator } \\
\text { reliability } \\
\text { composite }\end{array}$ & $\begin{array}{c}\text { Cronbach's } \\
\text { Alpha }\end{array}$ & \\
\hline \multirow{4}{*}{$\begin{array}{l}\text { Performance of the adoption } \\
\text { of Sustainable Finance } \\
\text { through the lens of } \\
\text { Responsible Management }\end{array}$} & \multirow{4}{*}{$\begin{array}{l}\text { Performance of } \\
\text { the adoption of } \\
\text { Sustainable } \\
\text { Finance through } \\
\text { the lens of } \\
\text { Responsible } \\
\text { Management }\end{array}$} & \multirow[t]{4}{*}{21} & \multirow[t]{4}{*}{4} & \multirow[t]{4}{*}{$67,208 \%$} & \multirow{4}{*}{0,818} & \multirow[t]{4}{*}{0,672} & Item1 & $(10,901)^{* * *}$ & \multirow{4}{*}{0,89} & \multirow[t]{4}{*}{0,834} & \\
\hline & & & & & & & Item2 & $(7,516) * * *$ & & & \\
\hline & & & & & & & Item3 & $(37,398) * * *$ & & & \\
\hline & & & & & & & Item4 & $(6,89)^{* * *}$ & & & \\
\hline \multirow[t]{3}{*}{ Strategy CDM } & \multirow[t]{3}{*}{ Strategy CDM } & \multirow[t]{3}{*}{7} & \multirow[t]{3}{*}{3} & \multirow[t]{3}{*}{$91,115 \%$} & \multirow[t]{3}{*}{0,946} & \multirow[t]{3}{*}{0,911} & Item1 & $(54,266) * * *$ & \multirow[t]{3}{*}{0,968} & \multirow[t]{3}{*}{0,951} & \multirow[t]{3}{*}{3} \\
\hline & & & & & & & Item2 & $(60,813) * * *$ & & & \\
\hline & & & & & & & Item3 & $\begin{array}{l}(101,278)^{* *} \\
*\end{array}$ & & & \\
\hline \multirow[t]{5}{*}{ Strategy JI } & \multirow[t]{5}{*}{ Strategy JI } & \multirow[t]{5}{*}{9} & \multirow[t]{5}{*}{7} & \multirow[t]{5}{*}{$93,818 \%$} & \multirow[t]{5}{*}{0,988} & 0,924 & Item1 & $(50,962) * * *$ & 0,984 & 0,979 & 5 \\
\hline & & & & & & & Item2 & $(62,979)^{* * *}$ & & & \\
\hline & & & & & & & Item3 & $(50,507) * * *$ & & & \\
\hline & & & & & & & Item4 & $\begin{array}{l}(112,586)^{* *} \\
*\end{array}$ & & & \\
\hline & & & & & & & Item5 & $(80,146)^{* * *}$ & & & \\
\hline Strategy PEN & Strategy PEN & 7 & 5 & $90,342 \%$ & 0,967 & 0,89 & Item1 & $(19,864) * * *$ & 0,97 & 0,959 & 4 \\
\hline & & & & & & & Item2 & $(21,628) * * *$ & & & \\
\hline & & & & & & & Item3 & $(7,411) * * *$ & & & \\
\hline & & & & & & & Item4 & $(21,464) * * *$ & & & \\
\hline Structure of compliance & Structure of & 35 & 4 & $78,061 \%$ & 0,943 & 0,532 & Item1 & $(12,886)^{* * *}$ & 0,885 & 0,85 & 7 \\
\hline NRE and ISO 26000 & compliance NRE & & & & & & Item2 & $(13,291)^{* * *}$ & & & \\
\hline & and ISO 26000 & & & & & & Item3 & $(4,566)^{* * *}$ & & & \\
\hline & & & & & & & Item4 & $(11,03)^{* * *}$ & & & \\
\hline & & & & & & & Item5 & $(2,547) * * *$ & & & \\
\hline & & & & & & & Item6 & $(7,729) * * *$ & & & \\
\hline & & & & & & & Item7 & $(8,11)^{* * *}$ & & & \\
\hline
\end{tabular}

sig. at the threshold of de $10 \% ; *^{*}$ : sig. at the threshold of de $5 \% ; * * *$ : sig. at the threshold of de $1 \%$

Source: Built by the authors using the Smart PLS 3.0 software package. 


\section{Methodology for specifying and testing the model structure}

The specification of the econometric model used to test the research model importance is monumental. In fact, on the map econometric, through specification consisting of the omission of explanatory variables in the model, in a form of specification is not adequate and a means of endogenous of the regressors, is the bias more damaging to the level of a regression model. Moreover, several authors warn that the studies testing conceptual models must take into account the effect of control variables on the one hand, and causal relations between the explanatory variables. In a second time, it is essential to comply with certain requirements imposed by the regression method used. This is the present case a set of assumptions underlying the estimator and the violation of which impairs the reliability and the validity of the model.

Table 1. Summary of the variables of the econometric model

\begin{tabular}{|c|c|c|c|c|}
\hline Entitled variables & Code & Nature & $\begin{array}{c}\text { Expected effect } \\
\text { on the } \\
\text { endogenous } \\
\text { variable } \\
\end{array}$ & Assumptions \\
\hline $\begin{array}{l}\text { Performance of the adoption of Sustainable } \\
\text { Finance through the lens of Responsible } \\
\text { Management }\end{array}$ & PAFCPMR & $\begin{array}{l}\text { Endogenous } \\
\text { Variable }\end{array}$ & & \\
\hline Strategy the Clean Development mechanism & SMDP & $\begin{array}{l}\text { Explanatory } \\
\text { Variable }\end{array}$ & Positive effect & H1 \\
\hline Strategy of Joint Implementation & SMCO & $\begin{array}{l}\text { Explanatory } \\
\text { Variable }\end{array}$ & Positive effect & $\mathrm{H} 2$ \\
\hline Strategy Permits to Emissions-Negotiable & SPEN & $\begin{array}{l}\text { Explanatory } \\
\text { Variable }\end{array}$ & Positive effect & $\mathrm{H} 3$ \\
\hline Structure of compliance NRE ISO 26000 & SCNREISO & $\begin{array}{l}\text { Explanatory } \\
\text { Variable }\end{array}$ & Positive effect & $\mathrm{H} 4$ \\
\hline $\begin{array}{l}\text { Company size (measured by the number of } \\
\text { permanent employees) }\end{array}$ & TEP & Control Variable & Positive effect & \\
\hline The territoriality of the company & Nationality & Control Variable & Positive effect & \\
\hline Contribution of renewable energy sources & SMOCENR & Control Variable & Positive effect & \\
\hline The emission of greenhouse gases & GES & Control Variable & Positive effect & \\
\hline Engineering training of top management & FormTMI & Control Variable & Positive effect & \\
\hline
\end{tabular}

Source: Built by the authors using the Smart PLS 3.0 software package.

For the estimation of the parameters of the model, we use a method non-parametric. Indeed, on the one hand the sample size is reduced to structural causes related to the characteristics of the research field, and on the other hand, the number of causal links specified is a result in order to avoid the bias of specification.

On the methodological plane, and having regard to the estimated non-parametric, the number of observation that must exist in order to estimate an econometric model must at least be equal to 10 observations per variable manifest in the built the most important (to explain) in the model, or 10 times the number of causal links. In both situations, we need to have a larger sample size of 100 observations that we reach from the method of the resampling. Thus, we generate a total of 300 samples from 40 observations for which we have, and the regression coefficient of the latent variable endogenous on each variable manifesto will be the average of all the 300 coefficients computed on each of the 300 samples (Chin, 1998).

We appreciate the reliability of our model by examining the conformity of the sign of each of its parameters to the conjectures made deductively. So, we're cutting off in favor of a reliable model if the parameters are consistent with theoretical predictions and are statistically significant at the $5 \%$ threshold. The following Figure puts into force our conceptual model: the built, the items and the control variables (Cf. Appendix no. 1: List of built and the items in the research model). 


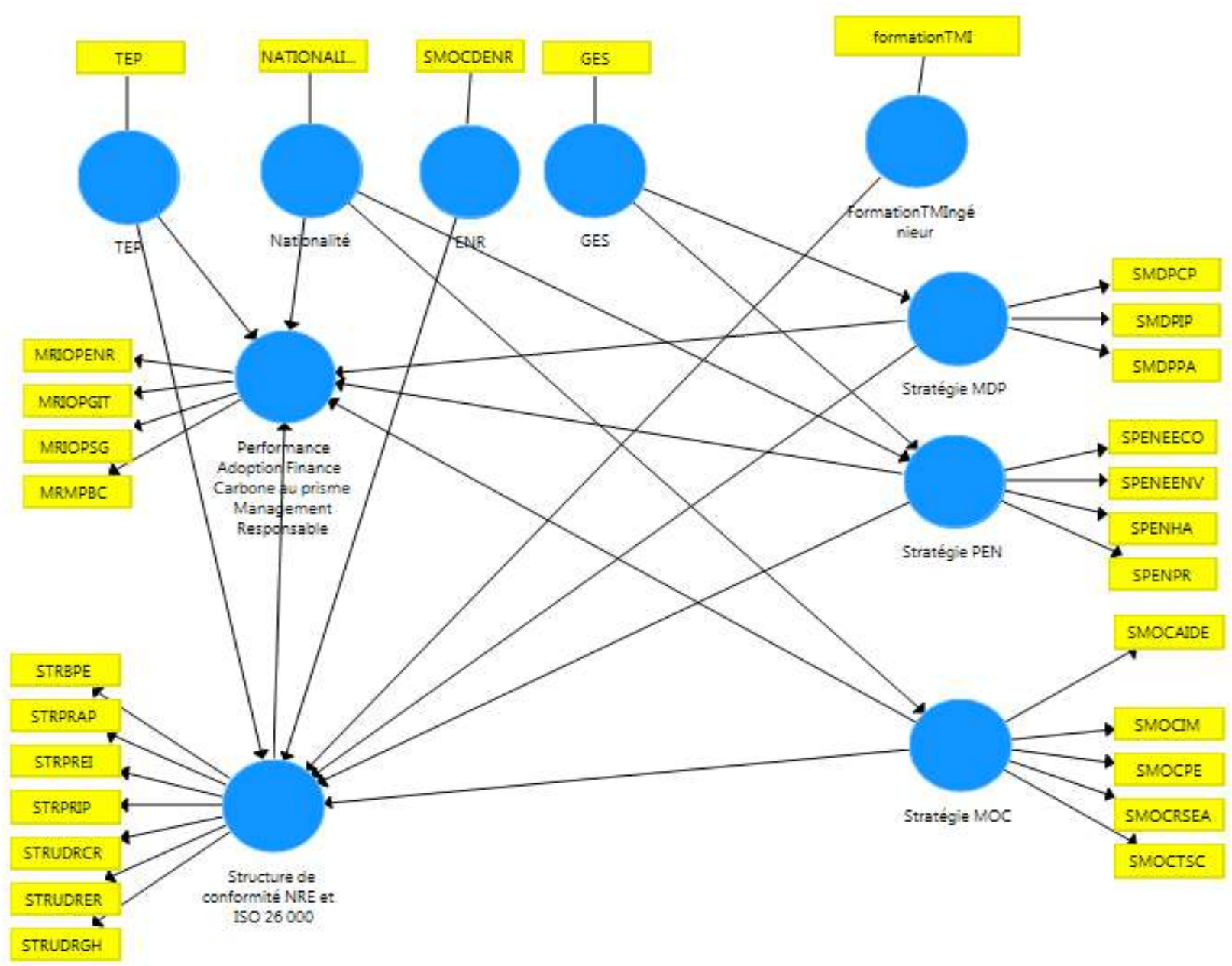

Figure 1. Conceptual Model established by the authors by means of the software Smart PLS 3.0

Source: Built by the authors using the Smart PLS 3.0 software package.

Our choice of using the approach to Partial Least Squares (PLS) to test our meta-search model is justified by the fact that it allows you to wear analyses on samples with reduced size (less than 100 observations). In this respect, our study looked at forty (40) companies that responded to our questionnaire, that we do not allow the use of other software such as LISREL (LInear Structural RELationships) ${ }^{1}$ require a minimum of 100 to 150 observations. To achieve this, we tested the structural relationships of our model, even the reflective nature of our built and vocation predictive of our model has led us to retain this method in the framework of the validation of our research model.

\section{The main results of the research and their discussion}

\subsection{Results of the validity of the measurement model}

We begin with the concept of the performance of the adoption of Sustainable Finance. Based on the operational definition of the concept, it is revealed that this latter can be operationalized using a total of 23 items. In fact, the sphere of influence is a broad concept has makes it difficult to identify across a few items all the more that the risk of access to the research field while being equipped with an insufficient number of items we had to persuade them to take all precautions deemed adequate by the integration of a large number of items. However, the exploratory factor analysis, we found that it is possible to capture the concept and to support it through only four dimensions. Certainly, the concept explains a total of $67,208 \%$ of the variability of the four items, with an internal consistency is very important reflecting the probative value of the Cronbach's Alpha equal to 0,818 . For this concept, the questions used to operationalize proved to be adequate

${ }^{1}$ The software SmartPLS is available under the link : http://www.smartpls.de/ 
because the results of the two analyses (exploratory and confirmatory) meet. Indeed, Confirmatory Factor Analysis (CFA) shows that, in fact, it is sufficient to use four items for which the average of the shared variance with the concept is $67.2 \%$ (in excess of 0.5 ), to the extent that their internal consistency measured by Cronbach's Alpha and consistency total after Factor Analysis Confirmatory (AFC) are respectively 0,834 and 0.89. Finally, Confirmatory Factor Analysis (AFC) based on the multiple regression shows that the regression of each of the variables manifest (items) on the latent variable (Performance of the Adoption of Sustainable Finance through the lens of Responsible Management) is significant at the 1\% threshold.

Results similar to those obtained for the concept of the performance of the adoption of Sustainable Finance is reach for the concept of the strategy CDM. In fact, to operationalize this concept it was necessary in a first time use of seven items, which were reduced to three items from the exploratory factor analysis. It in fact shows that the concept which is the latent variable manages to capture a total of $91,115 \%$ of the variance of the items. In addition, these items have a very good internal validity because they overlap each other at $91.1 \%$. These results endorse those of Confirmatory Factorial Analysis (AFC), which demonstrates that, in fact, it is sufficient to use three variables manifest (items) to make up the latent variable of the strategy CDM. Moreover, the average extracted variance is greater than 0.5 , denoting that the share of variance explained by the variance in latent in each of the variables manifest is greater than the portion attributable to the error. Finally, the confirmatory analysis allows you to decide in favour of a good reliability of the measurement instrument with respect to the internal consistency of the three items that measure the concept of the strategy CDM. Actually, the Cronbach's Alpha of 0,951 and the indicator of the coherence of a composite is equal to 0,968 .

The instrumentation of the concept of strategies JI has not experienced the same level of success as those of the performance of the adoption of Sustainable Finance and strategy JI. Indeed, the results of our analyses: exploratory and confirmatory were relatively divergent. In fact, the exploratory analysis allows to conclude that for measure the concept of policy JI, it has been necessary to use a total of 5 items and eliminating two items due to their low partial correlation with the other items. Thus, this purification allowed to have a construction in which the total variance with variables manifesto is to 93,818 , with an internal consistency expressed by a value of Cronbach's Alpha which is equal to 0,988. However, the use of the confirmatory analysis gives rise to a recommendation that it is necessary to keep an item that the exploratory analysis advocates reject. For our part, we rely on the results of this last analysis because it is based on the linear regression of each item on its latent variable. Aware of the superiority of this tool on the analysis of variance which takes into account the latent variable on the item without setting aside its effect on the other items, we'll build on the results of this regression. In this sense we retain in the end for this concept, a total of five variables obvious to operationalise. Confirmatory Factor Analysis (CFA) shows that these items and, where applicable, these latent variables share a total of $92.4 \%$, with their variable manifest and particularisent by the internal consistency was highly satisfactory, being reflected in higher values of the Cronbach's Alpha $(0,979)$ and the indicator of the reliability of the composite $(0,984)$.

We finally conclude by the Exploratory Factor Analysis (AFE) and Confirmatory (AFC) of the concept of the structure of compliance NRE and ISO 26000 . For this concept, and like the performance, the concern of not being able to operationalize adequately the concept, we are urged to be operationalized by a total of 35 latent variables, which we do not retain finally only seven. The level of this concept, also there was some dissent between the analyses: exploratory and confirmatory, on the number of items to be included to capture the concept. In fact, the first recommended a total of five items, whose validity and reliability was pretty convincing (with a total explained variance of $78,061 \%$ and a Cronbach's Alpha of 0.943). However, the confirmatory analysis is deemed to be more binding on the plan of the acceptance of the validity and reliability prodigal retain seven items in which the average variance extracted is barely acceptable $(0,532)$, and the Cronbach's Alpha as well as the coherence composite set of values finding a good internal consistency (respectively 0,885 and 0.85 ).

Are any, we conclude with results tending to validate the measurement model of the performance and strategy CDM with a confidence quite comforting. Furthermore, the measurement models of strategies JI and PEN will accept, with fairly good confidence, and, finally, we accept with caution the measurement model of the structure of compliance NRE and ISO 26000. 


\subsection{Results of testing assumptions of the structural model}

In order to test the structural model that highlights structural relations (Cf. Assumptions) between the latent variables, we use a method of explanation. Thus, as noted in the methodology, our sample of only 40 companies making the parametric methods are inapplicable. Thus, we estimate the parameters of the model econometric used as a means of testing the structural model by the method of partial least squares. In addition, we generate a total of 300 random samples from the 40 individuals using combinations without repetition of a few individuals chosen from aong the 40 individuals in our sample.

The estimation of the parameters is done by maximum likelihood on each of the 300 samples generated, and the value of each parameter in the model is the average of 300 different estimates, each corresponding to a sample. The table below records the results obtained following the estimation of the parameters of the model in question.

Table 4. Results of the estimation of the model parameters

\begin{tabular}{|c|c|c|c|c|}
\hline Title & Code & Nature & $\begin{array}{l}\text { Expected effect on the } \\
\text { endogenous variable }\end{array}$ & Assumptions \\
\hline $\begin{array}{l}\text { Performance of the adoption of } \\
\text { Sustainable Finance through the lens } \\
\text { of Responsible Management }\end{array}$ & PAFCPMR & \multicolumn{3}{|l|}{ Endogenous Variable } \\
\hline \multicolumn{5}{|c|}{ Variable explanatory predetermined } \\
\hline $\begin{array}{l}\text { Strategy Mechanisms of } \\
\text { the Clean Development (CDM) }\end{array}$ & SMDP & $\begin{array}{l}\text { Explanatory Variable } \\
\text { (predetermined) }\end{array}$ & Positive effect & H1 \\
\hline Strategy Joint Implementation (JI) & SMCO & $\begin{array}{l}\text { Explanatory Variable } \\
\text { (predetermined) }\end{array}$ & Positive effect & $\mathrm{H} 2$ \\
\hline $\begin{array}{l}\text { Strategy Permits to Emissions- } \\
\text { Negotiable (PEN) }\end{array}$ & SPEN & $\begin{array}{l}\text { Explanatory Variable } \\
\text { (predetermined) }\end{array}$ & Positive effect & $\mathrm{H} 3$ \\
\hline $\begin{array}{l}\text { Structure of compliance NRE ISO } 26 \\
000\end{array}$ & SCNREISO & $\begin{array}{l}\text { Explanatory Variable } \\
\text { (predetermined) }\end{array}$ & Positive effect & $\mathrm{H} 4$ \\
\hline \multicolumn{5}{|c|}{ Explanatory Variables control } \\
\hline $\begin{array}{l}\text { Company size (measured by the } \\
\text { number of permanent employees) }\end{array}$ & TEP & $\begin{array}{l}\text { Explanatory } \\
\text { (control) }\end{array}$ & Positive effect & \\
\hline The territoriality of the company & Nationality & $\begin{array}{l}\text { Explanatory } \\
\text { (control) }\end{array}$ & Positive effect & \\
\hline $\begin{array}{l}\text { Contribution of renewable energy } \\
\text { sources }\end{array}$ & SMOCENR & $\begin{array}{l}\text { Explanatory } \\
\text { (control) }\end{array}$ & Positive effect & \\
\hline The emission of greenhouse gases & GES & $\begin{array}{l}\text { Explanatory } \\
\text { (control) }\end{array}$ & Positive effect & \\
\hline $\begin{array}{llll}\begin{array}{l}\text { Engineering } \\
\text { management }\end{array} & \text { training } & \text { of } & \text { top } \\
\end{array}$ & FormTMI & $\begin{array}{ll}\begin{array}{l}\text { Explanatory } \\
\text { (control) }\end{array} & \text { Variable } \\
\end{array}$ & Positive effect & \\
\hline
\end{tabular}

Source: Built by the authors using the Smart PLS 3.0 software package.

We present the econometric model for the operationalization of the model structure. The system of equation below formalizes the econometric model used to test the model structure.

System of equation no. 1: The form of the equations of the econometric model for the operationalization of the model structure

$$
\begin{aligned}
& \text { PAFCPMR } R_{i}=\alpha_{1}+\alpha_{2} . S M D P_{i}+\alpha_{3} . S \text { MOC }_{i}+\alpha_{4} . \text { SPEN }_{i}+\alpha_{5} . \text { TEP }_{i}+\alpha_{6} . \text { Nationality }_{i} \\
& +\alpha_{7} . \text { SMOCENR }_{i}+\alpha_{8} . \text { GES }_{i}+\alpha_{9} . \text { FormTMI }_{i}+\alpha_{10} . \text { SCNREISO }_{i}+\epsilon_{i} \\
& \text { SCNREISO }_{i}=\beta_{1}+\beta_{2} \cdot \text { TEP }_{i}+\beta_{3} \cdot \text { ENR }_{i}+\beta_{4} \cdot M D P_{i}+\beta_{5} \cdot \text { PEN }_{i}+\beta_{6} \cdot \text { MOC }_{i}+\beta_{7} \cdot \text { FormTMI }_{i}+\epsilon^{\prime}{ }_{i} \\
& \text { PEN }_{i}=\gamma_{1}+\gamma_{2} \cdot G E S_{i}+\gamma_{3} . \text { Nationality }_{i}+\epsilon^{\prime \prime}{ }_{i} \\
& \llbracket M D P \rrbracket_{-} i=\delta_{-} 1+\delta_{-} 2 \text {. } \llbracket G E S \rrbracket_{-} i+\llbracket \epsilon^{\wedge \prime \prime \prime} \rrbracket_{-} i \\
& M O C_{i}=\theta_{1}+\theta_{2} \cdot G E S_{i}+\epsilon^{\prime \prime \prime \prime}{ }_{i}
\end{aligned}
$$

We begin by explaining the behavior of firms surveyed in terms of the Performance of the Adoption of Sustainable Finance to the test of Responsible Management. In our modelling, we have assumed that this performance can be explained by the implementation of strategies aimed at reducing emissions of Greenhouse Gas (GES) emissions, while controlling the effect of a combination of factors. In this regard, we controlled 
for the effect of the following factors : the nationality of the company, the conformity of its strategy and its structure to the objectives of the reduction of the environmental pollution, the training of the Top Management, the size of the company and its emissions of Greenhouse Gas (GES) emissions.

Table 5. The main results of the estimation of the model structure

\begin{tabular}{|c|c|c|c|c|c|}
\hline & $P A F C P M R_{i}$ & SCNREISO $_{i}$ & $P E N_{i}$ & $M D P_{i}$ & $M O C_{i}$ \\
\hline$S M D P_{i}$ & $(0,649) * *$ & $(0,788) * *$ & & & \\
\hline$S P E N_{i}$ & $(0,206)$ & $(0,332)$ & & & \\
\hline$S M O C_{i}$ & $(0,428)$ & $(1,532) *$ & & & \\
\hline$T E P_{i}$ & $(0,143)$ & $(0,018)$ & & & \\
\hline Nationality $_{i}$ & $(0,167)$ & & $(0,192)$ & & $(0,491) * * *$ \\
\hline \multicolumn{6}{|l|}{ SMOCENR $_{i}$} \\
\hline$G E S_{i}$ & & & $(0,311) * *$ & $(-0,72) * * *$ & \\
\hline FormTMI $_{i}$ & & $(0,095)$ & & & \\
\hline SCNREISO $_{i}$ & $(0,331) *$ & & & & \\
\hline$R^{2}$ & $(0,485) * * *$ & $(0,441) * * *$ & $(0,2)^{* *}$ & $(0,518) * * *$ & $(0,242) *$ \\
\hline$R_{\text {Ajusté }}^{2}$ & $(0,464) * * *$ & $(0,343) * * *$ & $(0,156)$ & $(0,504) * * *$ & $(0,222)$ \\
\hline
\end{tabular}

$*$ : sig. at the threshold of de $10 \% ; * *$ : sig. at the threshold of de $5 \% ; * * *:$ sig. at the threshold of de $1 \%$

Source: Built by the authors using the Smart PLS 3.0 software package.

The results of the estimation of the parameters of the structural model show that all coefficients gives the expected sign and two are statistically significant. In effect, the strategy CDM is a crucial staple of the Performance of the adoption of Sustainable Finance through the lens of Responsible Management. In addition, the structure of the compliance with NRE (New Economic Regulations) and ISO 26000 is a real factor for deploying Performance of the adoption of Sustainable Finance through the lens of Responsible Management.

\section{Conclusion}

The objective of this paper was to study the strategic involvement and the compliance of structural with respect to the environmental involvement and the impact of this involvement on the Performance of the Adoption of Sustainable Finance through the lens of Responsible Management in the moroccan context. To achieve this, we have been able to test the structural relationships of our model, on the one hand, the reflective nature of our built and vocation predictive of our model has led us to remember the method of Partial Least Squares (PLS) in the framework of the validation of our meta-model of research. On the other hand, our choice to use the approach of PLS is justified by the fact that this method to treat analyses on samples with reduced size ( $<100$ observations).

Force is to recognize that this action research is proposed to analyze the strategies and structures the Performance of the Adoption of Sustainable Finance at prism of the Kyoto Protocol. By doing this, an original declined by a meta-analysis of the strategies, structures, the Performance of the Adoption of Sustainable Finance, presented succinctly. What are the structures and strategies of Sustainable Finance to mitigate Climate Change (CC) in the Kyoto Protocol? Is there a meta-model for the study of the performativity of the adoption of Sustainable Finance through the lens of Responsible Management?

On this register, the european companies already have more of a head start on their counterparts in morocco. We wanted to check that it was actually on the field seem to measure the importance of strategic and structural Performance of the Adoption of Sustainable Finance through the lens of Responsible Management. Our study has identified two pillars are very important as managerial implications to the plan of the moroccan strategy CDM and the structure of the compliance with NRE (New Economic Regulations) and ISO 26000.

\section{References}

1. Alcott, B. (2008). The sufficiency strategy: Would rich-world frugality lower environmental impact?, Ecological Economics, 770-786. https://doi.org/10.1016/j.ecolecon.2007.04.015

2. Anderson, J. C. et Gerbing, D. W. (1988). Structural equation modelling in practice : A review and recommended two-step approach, Psychological bulletin, 103(3), 411-423. 
https://pdfs.semanticscholar.org/2265/a198e55665ed3df0f19688350567dab593de.pdf?.ga=2.21391144 7.1042702225.1590342168-1378669878.1588811588

3. Andreas Karaoulanis, A., Vasiliki, K. (2018). Tourism in Developing Countries. The Path Towards Sustainable Development and Its Interaction With The Local Communities, The Environment And The Hu-man Factor. SocioEconomic Challenges, 4(2), 80-86. https://doi.org/10.21272/sec.4(2).80-86.2018

4. Baron, R., Aasrud, A., Sinton, J., Campbell, N., Jiang, K. \& Zhuang, X. (2012). Policy options for low carbon power generation in china. International Energy Agency, Energy Research Institute, Insights Series. 74 p. http://www.iea.org/publications/insights/insightpublications/Insight PolicyOptions Low Carbon_China.pdf

5. Bhandari, M.P. (2019). Sustainable Development: Is This Paradigm the Remedy of All Challenges? Does Its Goals Capture the Essence of Real Development and Sustainability? With Reference to Discourses, Creativeness, Boundaries and Institutional Architecture. SocioEconomic Challenges, 3(4), 97-128. https://doi.org/10.21272/sec.3(4).97-128.2019

6. Bhowmik, D. (2019). Decoupling CO2 Emissions in Nordic countries: Panel Data Analysis. SocioEconomic Challenges, 3(2), 15-30. https://doi.org/10.21272/sec.3(2).15-30.2019

7. Bhowmik, D. (2018). Financial Crises and Nexus Between Economic Growth and

Foreign Direct Investment. Financial Markets, Institutions and Risks, 2(1), 58-74. http://doi.org/10.21272/fmir.2(1).58-74.2018

8. Boutti, R., El Amri, A., Rodhain, F. (2019). Multivariate Analysis of a Time Series EU ETS: Methods and Applications in Carbon Finance. Financial Markets, Institutions and Risks, 3(1), 18-29. http://doi.org/10.21272/fmir.3(1).18-29.2019.

9. Bożena, S., Vynnychenko, N. (2018). Evaluating of the financial equalization system in Ukraine. Financial Markets, Institutions and Risks, 2(1), 25-36. http://doi.org/10.21272/fmir.2(1).25-36.2018

10. Carbon Disclosure Project (CDP). (2010). Supply Chain Report. www.cdproject.net/CDPResults/CDPSupply-Chain-Report 2010.pdf

11. CCNUCC. (2007). Investment and Financial Flows to Address Climate Change. Secretariat of the United Nations Framework Convention on Climate Change, Bonn, 272 p. https://unfccc.int/resource/docs/publications/financial_flows.pdf

12. Chevallier, J. (2012). Econometric Analysis of Carbon Markets: the European Union Emissions Trading Scheme and the Clean Development Mechanism. Springer. https://www.springer.com/gp/book/ 9789400724112

13. Chin, W. W. (1998). The partial least squares approach to structural equation modeling. Modern methods for business research, 295(2), 295-336. https://psycnet.apa.org/record/1998-07269-010

14. Christensen, T. H., Godskesen, M. I., Gram-Hanssen, K., Quitzau, M-B., \& Røpke, I. (2007). Greening the Danes? Experience with consumption and environment policies. Journal of Consumer Policy, 30(2), 91-116. https://doi.org/10.1007/s10603-007-9029-2

15. Cosgrove-Sacks, C., Dembinski, P. H. (2009). Ehics In Finance: Surviving The Crisis. Finance \& Bien Commun, 1(33), 5-15. https://www.cairn.info/revue-finance-et-bien-commun-2009-1-page-5.htm

16. Dovhan, Z., Kravchuk, I., Karaś, P. (2017). The financial instruments market - an institutional approach. Financial Markets, Institutions and Risks, 1(1), 22-28. http://doi.org/10.21272/fmir.1(1).22-28.2017

17. Gadzo S. G., Anaman, Em. At., Pobbi, M., Asiamah, S. K. (2019). Industry Concentration and Asset Quality as Determinate of Financial Performance: A Comparative Study of Indigenous and Foreign Owned Universal Banks. Financial Markets, Institutions and Risks, 3(2), 79-90. http://doi.org/10.21272/fmir.3(2).79-90.2019

18. Heinemann, S. (2011). Financial Derivatives and Responsibility - How To Deal Ethically With Financial Risk. Finance \& Bien Commun, 1(39), 45-56. https://www.cairn.info/revue-finance-et-bien-commun-2011-1-page45.htm

19. IEA Ministerial Statement on Energy and Climate Change. (2015). Energy Matters : How COP 21 can shift the energy sector onto a low-carbon path that supports economic growth and energy access, International Energy Agency, 8 p. http://www.iea.org/media/presentations/ Energy Matters bro chure.PDF

20. International Renewable Energy Agency, IRENA. (2014). IRENA communiqué on the Africa clean energy corridor. Africa clean energy corridor ministerial, Abu Dhabi, United Arab Emirats. http://www.irena.org/DocumentDownloads/events/IRENA_ACEC_Communique_2014.pdf 
21. IPCC. (2014). Climate Change 2014 : Impacts, Adaptation, and Vulnerability Summary for Policymakers, Cambridge University Press, Cambridge, United Kingdom and New York, NY, USA, 44 p. https://ipccwg2.gov/AR5/images/uploads/IPCC_WG2AR5_SPM_Approved.pdf

22. Jaffe, A.B., R.G. Newell, \& R.N. Stavins (2004). Economics of energy efficiency. 79-90 in Cleveland, C.J. (ed), Encyclopedia of Energy, Volume 2, San Diego and Oxford (UK): Elsevier. https://scholar.harvard.edu/files/stavins/files/encyclopedia_of_energy 2004.pdf

23. Kasztelnik, K. (2020). Causal-Comparative Macroeconomic Behavioral Study: International Corporate Financial Transfer Pricing in the United States. Financial Markets, Institutions and Risks, 4(1), 60-75. http://armgpublishing.sumdu.edu.ua/journals/fmir/volume-4-issue-1/article-5/

24. Kostel, M., Leus, D., Cebotarenco, A., Mokrushina, A. (2017). The Sustainable Development Goals for Eastern Partnership Countries: Impact of Institutions. Socio-Economic Challenges, 1(3), 79-90. http://doi.org/10.21272/sec.1(3).79-90.2017

25. Nordhaus, W. D. (1991). To slow or not to slow: the economics of the greenhouse effect. Economic Journal, Vol. 101: 920- 937. https://www.jstor.org/stable/2233864? seq=1

26. OCDE. (2010). Climate Policy and Technological Innovation and Transfer: an overview of trends and recent empirical analysis: empirical results. www.oecd.org/dataoecd/54/52/45648463.pdf

27. Popoola, M. Ak., Brimah, Am. N., Gbadeyan, A. R. (2019). Financial Institutions Micro Loans: A Strategy for Reducing Poverty in Nigeria). Financial Markets, Institutions and Risks, 3(3), 1318.http://doi.org/10.21272/fmir.3(3). 13-17.2019.

28. Rubanov, P., Marcantonio, A. (2017). Alternative Finance Business-Models: Online Platforms. Financial Markets, Institutions and Risks, 1(3), 92-98. http://armgpublishing.sumdu.edu.ua/journals/fmir/issue-3/article-9/

29. Rydge, J. (2015). Implementing Effective Carbon Pricing : contributing paper for seizing the global opportnity partnerships for better growth and a better climate, New Climate Economy, London and Washington, DC. http://www.newclimateeconomy.report/misc/working-papers/

30. Sifah, D. (2009). Ethics: An Essential Prerequisite Of The Financial System. Finance \& Bien Commun, 1(33), 46-57. https://www.cairn.info/revue-finance-et-bien-commun-2009-1-page-46.htm

31. Singh, S.N. (2018). Regional Disparity and Sustainable Development in North-Eastern States of India: A Policy Perspective. Socio-Economic Challenges, 2(2), 41-48. http://doi.org/10.21272/sec.2(2).41$\underline{48.2018}$

32. UNEP FI. (2013). Portfolio carbon : measuring, disclosing and managing the carbon intensity of investments and investment portfolios. UNEP FI Climate Change Advisory and Investment Commission. $40 \mathrm{p}$.

http://www.unepfi.org/fileadmin/documents/UNEP_FI_Investor_Briefing_Portfolio_Carbon.pdf

33. Vargas-Hernández, J. G., Orozco-Quijano, E. P., Virchez, J. (2018). Critical Analysis On Institutional Capital On Trade And Environmentally Sustainable Development Under NAFTA. SocioEconomic Challenges, 4(2), 21-31. https://doi.org/10.21272/sec.4(2).21-31.2018

34. Vasilyeva, T., Lyeonov, S., Lopa, L. (2018). Forecasting Supply and Demand In the Regional Labor Market: In Search of Optimal Proportions of Financing Vocational Education Institutions In the Region. SocioEconomic Challenges, 2(1), 69-84. https://doi.org/10.21272/sec.2(1).69-84.2018

35. Wolrd Bank Group (2010). The economics of adaptation to climate change, The World Bank, Washington, D.C., 84 p.

http://siteresources.worldbank.org/EXTCC/Resources/EACC_FinalSynthesisReport0803_2010.pdf 


\section{Appendix 1}

Table 1. Performance Measure the adoption of Sustainable Finance through the lens of Responsible Management

\begin{tabular}{|c|c|c|}
\hline Dimensions & Labels of the items & Code items \\
\hline \multirow{4}{*}{$\begin{array}{l}\text { Performance of the } \\
\text { Adoption of Sustainable } \\
\text { Finance through the lens } \\
\text { of Responsible } \\
\text { Management }\end{array}$} & Responsible Management and integration tools: Renewable Energies & MRIOPENR \\
\hline & Responsible Management and integration tools: Green IT & MRIOPGIT \\
\hline & Responsible Management and integration of tools: Smart Grid & MRIOPSG \\
\hline & Responsible Management and implementation of a Carbon footprint & MRMPBC \\
\hline \multirow{7}{*}{$\begin{array}{l}\text { Structure of compliance } \\
\text { NRE and ISO } 26000\end{array}$} & $\begin{array}{l}\text { Structure of compliance NRE and ISO } 26000 \text { : responsible practices and } \\
\text { sustainable actions for the prevention of pollution and waste }\end{array}$ & STRPRAP \\
\hline & $\begin{array}{l}\text { Structure of compliance NRE and ISO } 26000 \text { : practices of identifying, } \\
\text { measuring and reporting of impacts on biodiversity and protection of } \\
\text { ecosystems }\end{array}$ & STRBPE \\
\hline & $\begin{array}{l}\text { Structure of compliance NRE and ISO } 26 \text { 000: practices for disposal of all } \\
\text { chemicals that are banned or identified as worrisome by scientific bodies or } \\
\text { stakeholders on the basis of reasonable evidence }\end{array}$ & STRPREI \\
\hline & $\begin{array}{l}\text { Structure of compliance NRE and ISO } 26 \text { 000: practices of public information } \\
\text { on the amounts and the nature of the toxic and hazardous substances used and } \\
\text { released, as well as the risks to which they are linked }\end{array}$ & STRPRIP \\
\hline & $\begin{array}{l}\text { Structure of compliance NRE and ISO } 26 \text { 000: promotion of sustainable } \\
\text { consumption }\end{array}$ & STRUDRCR \\
\hline & $\begin{array}{l}\text { Structure of compliance NRE and ISO } 26 \text { 000: programs resource-saving, } \\
\text { including the replacement of non-renewable resources by renewable resources } \\
\text { and sustainable }\end{array}$ & STRUDRER \\
\hline & $\begin{array}{l}\text { Structure of compliance NRE and ISO } 26000 \text { : guarantee to all users a access } \\
\text { to water resources in the basin of the activity }\end{array}$ & STRUDRGH \\
\hline \multirow{12}{*}{$\begin{array}{l}\text { Strategies To Finance } \\
\quad \text { Sustainable }\end{array}$} & $\begin{array}{l}\text { The Strategy CDM and preferences in terms of eligibility criteria for projects } \\
\text { (present or future) under the Clean Development mechanism (CDM): } \\
\text { preference additionality }\end{array}$ & SMDPPA \\
\hline & $\begin{array}{l}\text { The Strategy CDM and preferences in terms of eligibility criteria for projects } \\
\text { (present or future) under the Clean Development mechanism (CDM): } \\
\text { preference criterion of participation }\end{array}$ & SMDPCP \\
\hline & The Strategy CDM and degree of binding with the performance indicators & SMDPIP \\
\hline & $\begin{array}{l}\text { The Strategy JI building, at the local level, the brand image of the firm } \\
\text { developing the project, both at the level of the host country }\end{array}$ & SMOCIM \\
\hline & $\begin{array}{l}\text { The Strategy JI favouring the penetration of new technologies reducing GHG } \\
\text { emissions }\end{array}$ & SMOCTSC \\
\hline & $\begin{array}{l}\text { The Strategy JI promoting the operationalization of the policy of Social and } \\
\text { Environmental Responsibility (CSR) of the firm }\end{array}$ & SMOCRSEA \\
\hline & $\begin{array}{l}\text { The Strategy JI that contribute to the increase of Foreign Direct Investment } \\
\text { (FDI) in the recipient country of the project }\end{array}$ & SMOCAIDE \\
\hline & The Strategy JI that contribute to the protection of the environment & SMOCPE \\
\hline & The Strategy PEN requiring a criterion of Effectiveness Economic & SPENEECO \\
\hline & The Strategy PEN requiring a criterion of Environmental Efficiency & SPENEENV \\
\hline & The Strategy PEN requiring a criterion dealing with the issue of Hot Air & SPENHA \\
\hline & The Strategy PEN and the use of the purchase price of profitable guaranteed & SPENPR \\
\hline
\end{tabular}

Source: Built by the authors using the Smart PLS 3.0 software package. 


\section{Appendix 2}

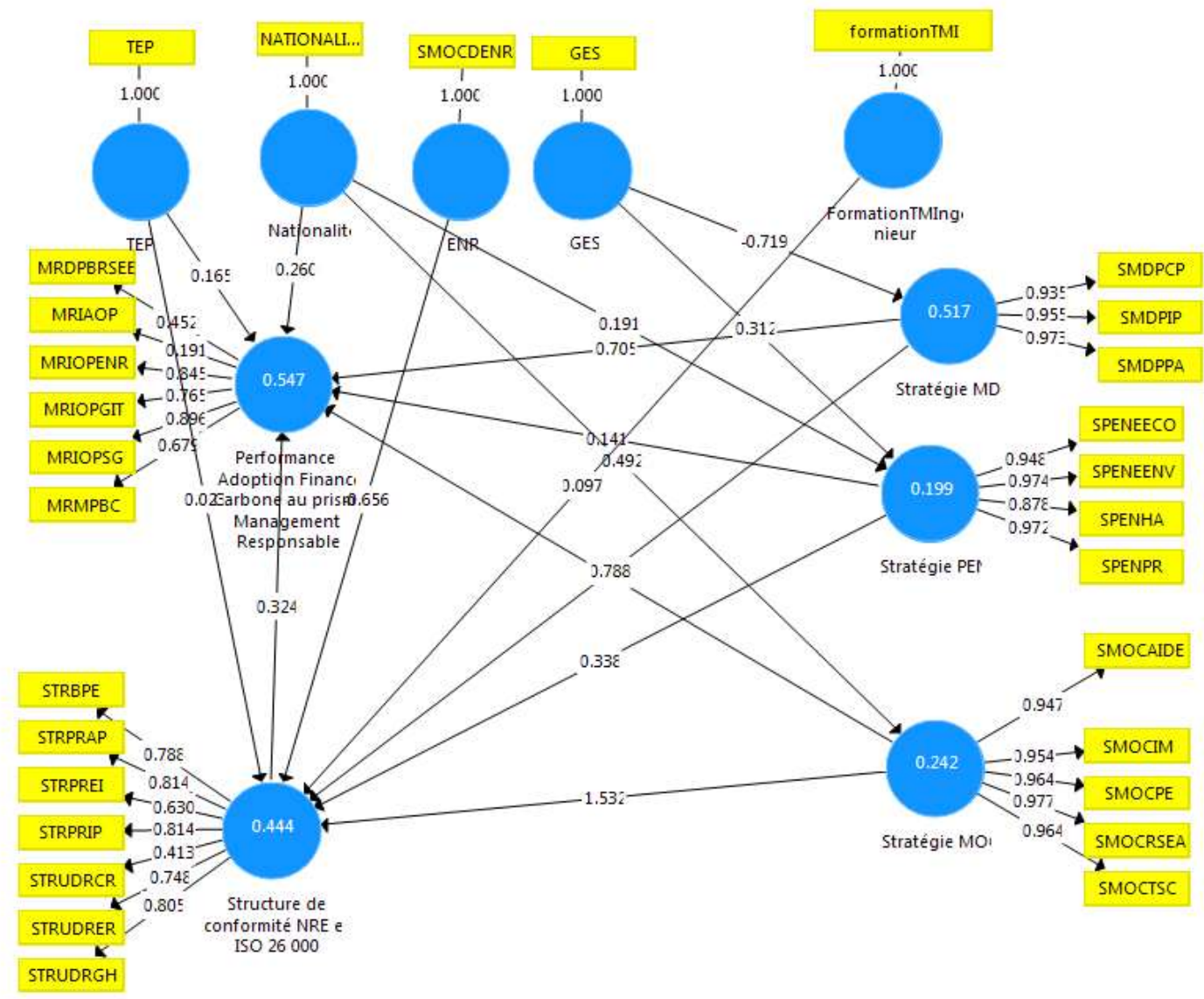

Figure 1. Meta-model is identified, estimated and validated sets by the authors using the software Smart PLS 3.0

Source: Built by the authors using the Smart PLS 3.0 software package.

Table of the results of the estimation of the structural model established by the authors by means of the software Smart PLS 3.0

\begin{tabular}{|c|c|c|c|c|c|}
\hline ENR $\rightarrow$ Structure de conformité NRE et ISO 26000 & -0.657 & -0.731 & 0.869 & 0.755 & 0.450 \\
\hline FormationTMIngénieur - > Structure de conformité NRE et ISO 26000 & 0.095 & 0.109 & 0.206 & 0.462 & 0.645 \\
\hline GES -> Stratégie MDP & -0.720 & -0.716 & 0.113 & 6.389 & 0.000 \\
\hline GES $\rightarrow$ Stratégie PEN & 0.311 & 0.316 & 0.167 & 1.864 & 0.063 \\
\hline Nationalité $>>$ Performance Adoption Finance Carbone au prisme Management Responsable & 0.167 & 0.152 & 0,302 & 0.553 & 0.581 \\
\hline Nationalité -> Stratégie MOC & 0.491 & 0.494 & 0.153 & 3.220 & 0.001 \\
\hline Nationalité -> Stratégie PEN & 0.192 & 0.184 & 0.228 & 0.841 & 0.401 \\
\hline Stratégie MDP $\rightarrow$ Pefformance Adoption Finance Carbone au prisme Management Responsable & 0.649 & 0.709 & 0.314 & 2.065 & 0.039 \\
\hline Stratégie MDP $\rightarrow$ Structure de conformité NRE et 15026000 & 0.788 & 0.735 & 0.311 & 2.532 & 0.012 \\
\hline Stratégie MOC $>>$ Pefformance Adoption Finance Carbone au prisme Management Responsable & 0.428 & 0.478 & 0.439 & 0.976 & 0.329 \\
\hline Stratégie MOC $\rightarrow$ Structure de conformité NRE et ISO 26000 & 1,532 & 1.550 & 0.877 & 1.747 & 0.081 \\
\hline Stratégie PEN - > Performance Adoption Finance Carbone au prisme Management Responsable & 0.206 & 0.246 & 0.396 & 0.520 & 0.603 \\
\hline Stratégie PEN $\rightarrow$ Structure de conformité NRE et ISO 26000 & 0.336 & 0.307 & 0.216 & 1.556 & 0.120 \\
\hline Structure de conformité NRE et ISO $26000 \rightarrow$ Performance Adoption Finance Carbone au prisme Management Responsable & 0.331 & 0.303 & 0.186 & 1.780 & 0.076 \\
\hline TEP -> Performance Adoption Finance Carbone au prisme Management Responsable & 0.143 & 0.120 & 0.128 & 1.116 & 0.265 \\
\hline TEP $\rightarrow>$ Structure de conformité NRE et ISO 26000 & 0.018 & 0.042 & 0.136 & 0.133 & 0.894 \\
\hline
\end{tabular}

Source: Built by the authors using the Smart PLS 3.0 software package. 